\title{
Determinants of banks' net interest margins in Central and Eastern Europe
}

\author{
MIRNA DUMIČIĆ*
}

TOMISLAV RIDZAK*

\section{Article**}

JEL: G21, G15

doi: $10.3326 /$ fintp.37.1.1

* The views expressed in the paper are authors' own, and do not necessarily represent the views of the Croatian National Bank. The authors would like to thank two anonymous referees for their useful comments and suggestions.

** Received: June 1, 2012

Accepted: November 21, 2012

The article was awarded as the best regular category paper in the annual award of the Prof. Dr. Marijan Hanžeković Prize for 2012.

\section{Mirna DUMIČIĆ}

Croatian National Bank, Trg hrvatskih velikana 3, 10000 Zagreb, Croatia

e-mail: mirna.dumicic@hnb.hr

Tomislav RIDZAK

Croatian National Bank, Trg hrvatskih velikana 3, 10000 Zagreb, Croatia

e-mail: tomislav.ridzak@hnb.hr 


\begin{abstract}
This research analyzes the main determinants of the net interest margin of banks operating in Central and Eastern European (CEE) countries in the period from 1999 to 2010. The results reveal several main drivers of net interest margins in the CEE. Prior to 2008 the net interest margins declined primarily due to strong capital inflows and stable macroeconomic environment. In the crisis period, significant rise in government debt accompanied by the increase in macroeconomic risks and abating capital inflows were pushing margins up while other factors such as low credit demand, higher capitalization and significantly increased share of non-performing loans pressured banks'margins down. The results also confirm the important contribution of higher efficiency to lowering banks' margins.
\end{abstract}

Keywords: net interest margin, CEE

\title{
1 INTRODUCTION
}

The past few years in some of the Central and Eastern European ${ }^{1}$ (CEE) countries have been marked by an ongoing debate among politicians, the financial industry academic community and the general public about banking sector profitability, which has been characterized both as too high and too low, depending on the point of view. There have also been many opposite opinions about the role of banks and their ability to promote the recovery of the real economy, especially in countries where credit activity is stagnating or is very low. In that context, one of the main questions raised has been related to the banks' and policymakers' options of lowering domestic interest rates and stimulating demand for credit in such a way.

The cost of financial intermediation is an important determinant of total financing costs. According to the literature (i.e. Maudos and de Guevarra, 2004; Claeys and Vander Vennet, 2008; Kasman et al., 2010) there is a strong connection between the degree and cost of financial intermediation and economic growth, as funding costs have a significant impact on the investment level and capital allocation, and thus in turn on growth potential and the direction of economic activity. They also affect the profitability of the banking sector and therefore its stability and ability to support the real economy (García-Herrero, Gavilá and Santabárbara, 2009).

In spite of the importance of borrowing conditions for economic recovery and, in turn, for financial system stability, this area has not been researched extensively with respect to CEE countries in the period during and after the onset of the recent financial crisis. Most of the papers studying the net interest margins in these countries focus on the period of banking sector consolidation in the early 2000s and the post-consolidation period, which has been marked by a successful transformation of those banks into modern, market-oriented financial institutions. However, the recent crisis, marked by a severe slowdown and drop in real GDP and

\footnotetext{
${ }^{1}$ Bulgaria, Croatia, Czech Republic, Estonia, Hungary, Latvia, Lithuania, Poland, Romania, Slovak Republic and Slovenia.
} 
mostly very slow (if any) recovery combined with very mild credit activity of commercial banks, has drawn lots of attention to the interconnectedness between financial institutions and the real economy.

Banks charge and pay many types of interest rates and have a variety of different categories of assets and liabilities and there is no unique way of measuring the difference between what they charge for lending and the price of their funding sources. One of the best and most widely used indicator of the cost and efficiency of financial intermediation is a bank's net interest margin. It is calculated as the ratio of net interest income and total bank earning assets, where net interest income is equal to the difference between interest earned and interest paid. Regardless of its common use, it should be noted that this indicator has some potential weaknesses, as it does not take into account other sources of income and costs for the bank and is not good representative of a bank's marginal costs and revenues (for details see Brock and Suarez, 2000).

Higher net interest margins usually imply lower banking sector efficiency, marked by higher costs due to inefficient control of operating expenses, and have a negative impact on financial developments, resulting with lower investments and slower economic activity. They might also reflect a high risk premia due to inappropriate regulation of the banking sector or a significant information asymmetry (Claeys and Vander Vennet, 2008). On the other hand, lower net interest margins usually mark deeper and more developed financial markets, encourage investment activities and support economic growth. However, as emphasized by Schweiger and Liebeg (2009), the benefits of a lower cost of financial intermediation will only be effectuated if banks price risks in a prudent manner.

From banks' perspective, the net interest margin is an important determinant of their profitability, while from the real economy point of view, combined with the country risk, macroeconomic variables, client risk, competition, etc. it is one of the key factors influencing the overall level of interest rates for the private sector. In bank-centric systems dominant in European emerging markets where bank loans are the main funding source, factors that affect loan availability also influence the stability of the whole banking sector.

This research aims to find the main determinants of the net interest margin in eleven CEE countries: Bulgaria, Croatia, Czech Republic, Estonia, Hungary, Latvia, Lithuania, Poland, Romania, Slovak Republic and Slovenia. The total sample consists of 12 periods (from 1999 to 2010) and 152 cross sections (banks). We are particularly interested to find out how bank-specific variables are important for the level of net interest margin compared to the specific conditions in the country where bank operates. 
One of the main contributions of this paper to the existing literature is its analysis of the period after the onset of the financial crisis, which has not yet been done for this region. Apart from that, we use the Arellano and Bover (1995) system GMM estimator, which solves endogeneity problems and allows for the inclusion of a lagged dependent variable together with fixed effects to control for unobserved heterogeneity. Unlike most other papers dealing with CEE countries, we also take into account regulatory costs.

The results reveal several main drivers of net interest margins in CEE. Prior to 2008 the net interest margins declined primarily due to strong capital inflows and the stable macroeconomic environment. In the crisis period, a significant rise in government debt accompanied by the increase in macroeconomic risks and abated capital inflows pushed margins up while other factors such as low demand (due to weak economic performance), higher capitalization and significantly increased share of non-performing loans pressured banks' margins down. The results also confirm the important contribution of higher efficiency to lowering banks' margins. This leads to the conclusion that policymakers can influence the costs of financial intermediation by conducting prudent and sustainable policies aimed at preventing and mitigating risk accumulation and creating a stable macroeconomic environment, accordingly indirectly supporting economic activity.

The rest of the paper is organized in the following way. Section two summarizes the main findings from the literature investigating the main determinants of banks' profitability and costs of financial intermediation. The third section describes the data used in the empirical part of the paper, section four gives an overview of stylized facts, while the methodology is explained in the fifth part. The main results and robustness checks are presented in section six. Concluding remarks, as well as some policy implications based on the research outcome, are provided in the seventh section.

\section{LITERATURE SURVEY}

Table A1 (in the appendix) presents some of the most relevant research papers that study banks' efficiency and the cost of financial intermediation. The main question posed in the literature relates to the fundamental elements that influence the cost of financial intermediation. The literature identifies several prime drivers of net interest margins (managerial efficiency, macroeconomic volatility and competitive pressures). Regarding policy-related questions, the literature has looked into the role of macroeconomic, financial stability and regulatory policies as determinants of interest margins. For instance, one question relates to potential role of central banks in lowering interest rate volatility (Saunders and Schumacher, 2000) or the role of banking sector regulation in fostering market competition, building up stronger capital adequacy rules, lowering credit risk and thereby affecting net interest margins (e.g. Claeys and Vander Vennet, 2008; Maudos and de Guevara, 2004; Hasan Khan and Khan, 2010). 
In terms of the empirical framework most of the papers base their empirical research on the microeconomic dealership model introduced by Ho and Saunders (1981), who view the bank as a dealer facing uncertainty and costs coming from the stochastic nature of loan demand and deposit inflows, which are covered by different fees. There are three empirical approaches in estimating this model, depending on the availability of the data and the interest of the researchers.

The first approach is based on a two-step procedure, where in the first step the net interest margins are regressed on a set of bank specific explanatory variables. The resulting constant in this regression is a measure of the pure interest margin for the country in question, which is calculated for each time period. In the second step, the time series of pure interest rate spread is regressed on the second set of explanatory variables: macroeconomic variables, interest rates and their volatility. The constant term in this step reflects the effects of market structure on the spread determination after bank specific and macroeconomic effects have been cleaned out. Such an approach is characteristic of a single-country analysis with long time series (Brock and Suarez, 2000; Saunders and Schumacher, 2000; and Männasoo, 2010). In Männasoo (2010) second step regression is done by vector error correction model.

The second type of empirical approach was to use the single step approach and estimate a reduced equation that depicts the banks' behaviour with respect to various determinants of net interest margin. This approach has been mainly used in cross-country studies, where in addition to bank and banking market specific variables researchers also include macroeconomic variables to capture the effect of banks' country of operation characteristics. Apart from that, the variables used are the same as those in the previous approach. In terms of estimation techniques, this approach uses estimates on a pooled dataset, generalized least squares or least squares with fixed effects (Claeys and Vander Vennet, 2008; Maudos and de Guevara, 2004; Kasman et al., 2010; and Hasan Khan and Khan, 2010).

The third type of empirical approach builds on the second, but extends it empirically. Several potential problems are addressed here. The first is that the net interest margins show a tendency to persist over time, which could be a sign of competitive position of the bank, serially correlated macroeconomic shocks and information opacity (Dietrich and Wanzenried, 2011). An additional problem could be endogeneity. As García-Herrero et al. (2009) explain, more profitable banks may be able to increase their equity more easily by retaining profits or they could invest in advertising campaigns to increase size, which can increase their profitability. Finally, as before, the researcher needs to take care of unobservable heterogeneity which is usually controlled by using fixed effects. This is why some authors opted for the GMM estimator which solves these problems (García-Herrero, Gavilá and Santabárbara, 2009; Dietrich and Wanzenried, 2011). 
Apart from the net interest margin some authors use different variables as an alternative proxy for bank profitability and cost of financial intermediation such as return on average assets (ROAA) and return on average equity (ROAE) (Athanasoglou, Delis and Staikouras, 2006; Dietrich and Wanzenried, 2011).

The literature surveyed shows that the characteristics of the individual banks are among the most important determinants of banks' business results and financing costs for their clients. Variables most commonly used for this purpose are different items (or their ratios) from financial and other reports that measure operational efficiency, quality of management, income structure, balance-sheet structure, credit activity, capital adequacy, liquidity, risk aversion, loan quality, credit risk, interest risk, opportunity costs of bank reserves, as well as bank size and ownership structure.

Conclusions about the impact of macroeconomic conditions on interest margins and banking sector efficiency have been ambiguous. Uncertainty and deterioration in macroeconomic conditions might increase interest margins and vice versa, but as mentioned by Claeys and Vander Vennet (2004), higher economic growth could also result in higher interest margins due to more intense credit activity and better loan quality. One of the things most authors agree on is that lower inflation implies lower interest margins.

Due to the problems with measurement, few papers explore the impact of regulatory costs on the cost of financial intermediation. Ho and Saunders (1981) emphasize that the cost of banks' funds is affected not only by the level of reserve requirements, but also by the opportunity cost of holding reserves usually measured by short-term risk free rate. Brock and Suarez (2000) and Saunders and Schumacher (2000) agree that higher reserve requirements get translated into higher interest spreads.

The influence of banking market structure on banks' efficiency has been investigated in many papers and is commonly measured by the Herfindahl index ${ }^{2}$ or Lerner index ${ }^{3}$. Specific features of the banking markets influence the market power of each specific bank and impact the pricing policy, and therefore can pressure net interest margins. This implies that a more competitive environment should be able to support lower interest margins, but as mentioned in Dietrich and Wanzenried (2011), higher concentration might also be a consequence of a strong competition among banks and therefore result in lower interest margins. Another way of looking at the impact of competition, as noted by Claeys and Vander Vennet (2004) and Schweiger and Liebeg (2009), is that it might encourage banks to take a higher risk or not price it adequately, resulting in suboptimal interest margins and potentially leading to the instability of the whole banking sector.

\footnotetext{
${ }^{2}$ Sum of the squares of market shares in total assets of the individual banks.

${ }^{3}$ Proxy of market power $=($ Total Revenue - Total Cost $) /$ Total Revenue.
} 
We analyse banks from $11 \mathrm{CEE}$ countries, and the sample consists of 12 periods (from 1999 to 2010) and 152 cross sections. For the full sample this gives the minimum of 823 observations, after the missing bank-year items were deleted. Table 1 lists the data used together with the sources and descriptions. Before the econometric analysis the data were revised and checked for extreme values and possible reporting errors. Table A2 in the appendix presents descriptive statistics for the panel data set used in the analysis. All variables have also been checked for stationarity using panel unit root test (table A3), but it is important to note that due to limited time dimensions these tests might have a low power.

The dependent variable in the empirical part of research is the net interest margin. It measures the cost and efficiency of financial intermediation and is determined by the variables that can be influenced by a bank's management, as well as by environmental variables that are primarily features of the market and country where the bank operates, mostly outside the management's control.

Explanatory variables are divided into three groups: bank specific variables, country specific macroeconomic characteristics and banking market specific variables (table 1).

While measuring the impact of the bank specific variables we focus on several major factors that contribute to the bank's performance: efficiency in conducting its operations, risk, leverage, possible substitution between interest and non-interest revenues and finally, benefits of the economy of scale.

Cost to income ratio measures the banks' efficiency. This variable shows how expensive it is for a bank to produce a unit of operating income in terms of costs not related to interest expense. It is expected that banks with high unit costs require higher margins in order to cover these expenses (Maudos and de Guevara, 2004), while at the same time higher operational efficiency allows banks to lower interest margins through lower loan rates or higher deposit rates (Claeys and Vander Vennet, 2008).

Banks might be willing to forgo part of their interest income if they substitute other forms of income for it, i.e. fees and commissions on other services. As found by Kasman et al. (2010), this substitution effect might be very important in explaining the level of net interest margin. This is why some banks have lower interest rates for clients that use a group of other services provided by the bank. 
Table 1

Data description

\begin{tabular}{|c|c|c|c|c|c|c|}
\hline Category & $\begin{array}{l}\text { Designation } \\
\text { in the } \\
\text { formula } \\
\end{array}$ & Name & Unit & Description & Source & $\begin{array}{c}\text { Expected } \\
\text { effect }\end{array}$ \\
\hline $\begin{array}{l}\text { Dependent } \\
\text { variable }\end{array}$ & y & $\begin{array}{l}\text { Net interest } \\
\text { margin }\end{array}$ & $\%$ & $\begin{array}{l}\text { Net interest income divided } \\
\text { by average earning assets. Net } \\
\text { interest income is defined as } \\
\text { the gross interest income plus } \\
\text { dividend income. }\end{array}$ & BankScope & $\mathrm{n} / \mathrm{a}$ \\
\hline \multirow{5}{*}{$\begin{array}{l}\text { Bank } \\
\text { specific } \\
\text { variables }\end{array}$} & \multirow{5}{*}{$x$} & $\begin{array}{l}\text { Cost to } \\
\text { income ratio }\end{array}$ & $\%$ & $\begin{array}{l}\text { Measure of operating efficiency } \\
\text { is calculated as the ratio of } \\
\text { sum of personnel expenses and } \\
\text { operating expenses such as } \\
\text { depreciation, amortisation, } \\
\text { administrative expenses, } \\
\text { occupancy costs, software } \\
\text { costs, operating lease rentals, } \\
\text { audit and professional fees and } \\
\text { other operating expenses of an } \\
\text { administrative nature and } \\
\text { operating income before } \\
\text { provisions. Measures costs } \\
\text { of running the bank as } \\
\text { percentage of income generated } \\
\text { before provisions. }\end{array}$ & BankScope & - \\
\hline & & $\begin{array}{l}\text { Total capital } \\
\text { ratio }\end{array}$ & $\%$ & $\begin{array}{l}\text { Total capital adequacy measure. } \\
\text { It combines Tier } 1 \text { and Tier } 2 \\
\text { capital as a percentage of risk } \\
\text { weighted assets. Proxy for a } \\
\text { regulatory cost related to capital } \\
\text { adequacy requirements. }\end{array}$ & BankScope & + \\
\hline & & $\begin{array}{l}\text { Ratio of } \\
\text { noninterest } \\
\text { revenue to } \\
\text { gross revenue }\end{array}$ & $\%$ & $\begin{array}{l}\text { Measures the revenues the banks } \\
\text { have from other services such } \\
\text { as fees and commissions. Higher } \\
\text { revenue from such sources } \\
\text { might be a compensation for } \\
\text { lower interest revenues. }\end{array}$ & BankScope & - \\
\hline & & $\begin{array}{l}\text { Ratio of loans } \\
\text { to customer } \\
\text { deposits }\end{array}$ & $\%$ & $\begin{array}{l}\text { This liquidity or funding ratio } \\
\text { indicates to what extent the } \\
\text { bank's relatively illiquid loans } \\
\text { are funded by relatively stable } \\
\text { customer deposits rather than } \\
\text { wholesale or market funding. }\end{array}$ & BankScope & $+1-$ \\
\hline & & $\begin{array}{l}\text { Ratio of } \\
\text { reserves for } \\
\text { impaired loans } \\
\text { to impaired } \\
\text { loans }\end{array}$ & $\%$ & $\begin{array}{l}\text { A higher ratio implies better } \\
\text { provisions of the bank for } \\
\text { bad loans and assets quality. }\end{array}$ & BankScope & $+1-$ \\
\hline
\end{tabular}




\begin{tabular}{|c|c|c|c|c|c|c|}
\hline Category & $\begin{array}{c}\text { Designation } \\
\text { in the } \\
\text { formula }\end{array}$ & Name & Unit & Description & Source & $\begin{array}{l}\text { Expected } \\
\text { effect }\end{array}$ \\
\hline $\begin{array}{l}\text { Banking } \\
\text { market } \\
\text { specific } \\
\text { variables }\end{array}$ & w & Concentration & $\%$ & $\begin{array}{l}\text { Share of total assets in a country } \\
\text { held by three largest banks. }\end{array}$ & $\begin{array}{l}\text { Own cal- } \\
\text { culation, } \\
\text { BankScope } \\
\text { data }\end{array}$ & $+/-$ \\
\hline \multirow{7}{*}{$\begin{array}{l}\text { Macro- } \\
\text { economic } \\
\text { variables }\end{array}$} & \multirow{7}{*}{ Z } & GDP growth & $\%$ & Growth rate of real GDP. & Eurostat & + \\
\hline & & $\begin{array}{l}\text { Current } \\
\text { account }\end{array}$ & $\%$ & $\begin{array}{l}\text { Ratio of current account } \\
\text { balance to GDP. }\end{array}$ & Eurostat & + \\
\hline & & $\begin{array}{l}\text { Government } \\
\text { debt }\end{array}$ & $\%$ & $\begin{array}{l}\text { Ratio of general government } \\
\text { consolidated debt to GDP. }\end{array}$ & Eurostat & + \\
\hline & & Inflation & $\%$ & $\begin{array}{l}\text { Average annual rate of change } \\
\text { of HICP. }\end{array}$ & Eurostat & $+1-$ \\
\hline & & $\begin{array}{l}3 \text { month } \\
\text { money market } \\
\text { rate }\end{array}$ & $\%$ & $\begin{array}{l}\text { Domestic money market interest } \\
\text { rate. }\end{array}$ & Eurostat & + \\
\hline & & $\begin{array}{l}\text { Country } \\
\text { spread }\end{array}$ & $\begin{array}{l}\text { basis } \\
\text { points }\end{array}$ & $\begin{array}{l}\text { Spreads on international } \\
\text { government bonds, own } \\
\text { calculation based on Merrill } \\
\text { Lynch government bond yield } \\
\text { data. }\end{array}$ & Bloomberg & - \\
\hline & & $\begin{array}{l}\text { Regulatory } \\
\text { cost }\end{array}$ & $\%$ & $\begin{array}{l}\text { Calculated as the ratio of bank } \\
\text { reserves held at central bank and } \\
\text { M3, this variable serves as a } \\
\text { proxy for a part of the regulatory } \\
\text { costs. }\end{array}$ & IFS & + \\
\hline
\end{tabular}

Credit risk belongs to the group of factors with the highest impact on banks' interest margins (Schweiger and Liebeg, 2009; Saad and El-Moussawi, 2010). Following Maudos and de Guevara (2004) and Kasman et al. (2010), it is proxied by the ratio of loans to total assets. Banks are expected to charge higher interest rates in order to compensate for higher credit risk. In that context, Athanasoglou, Delis and Staikouras (2006) emphasize the importance of credit risk management, which has not always been appropriate in the SEE region.

The ratio of loans to customer deposits represents a proxy for the liquidity risk, which has become particularly significant during the financial crisis when the interbank market was almost frozen and marked by liquidity hoarding, a drop in volume and an increase in the interbank interest rates in the EU (Heider, Hoerova and Holthausen, 2009; Gabrielli, 2010). Apart from that, banks in the CEE countries might have also been affected by deleveraging as their owners need to fulfil tougher capital requirements ${ }^{4}$. The impact of this ratio on the net interest margin

\footnotetext{
${ }^{4}$ Speech of the Hungarian Central Bank Governor at G20 meeting, available at http://www.ebrd.com/ downloads/news/simor-andras.pdf.
} 
can be ambiguous, depending on whether deposits are cheaper than wholesale funding.

Capital adequacy ratio is a standard proxy for the creditworthiness of the bank. Capital adequacy rules are set by the regulator with the aim of preventing banks from accepting too much risk and ensuring banking sector stability (Claeys and Vander Vennet, 2008), although the actual level of capital adequacy that bank maintains is a result of combination of factors (regulation, market pressures, business strategy of the bank). Expected sign of relationship between net interest margin and capital adequacy ratio can go both ways, depending on the magnitude of transfer of these factors to clients. According to Saunders and Schumacher (2000), it is expected that banking systems with lower regulatory costs (such as reserve and capital requirements) have narrower margins.

An additional measure of regulatory costs is a ratio of bank reserves held at the central bank and M3. It is expected that countries with higher costs of regulation will have more reserves placed with the central bank. We are aware that such a measure has some drawbacks but we believe that in the studied period it is a good proxy for regulatory costs in the CEE countries.

The influence of non-performing loans on the net interest margins is measured by the coverage of impaired loans with reserves. The rise in the share of non-performing loans and increased reservations for bad loans hurt bank's profitability, especially during the crisis. International accounting standards (IAS 39) stipulate that the interest on the loan that is impaired is accrued only on the recoverable amount ${ }^{5}$. Provisions for bad loans can also be used as tool for income smoothing, where in good times provisions are on a level higher than the expected loss and in bad times they are underrated, as documented by Fonesca and Gonzales (2008). Consequently, the link between nonperforming loans and net interest margin might be ambiguous.

The influence of market structure on the net interest margin is measured by the share of the three largest banks in total assets of the banking sector. A more concentrated banking market might imply higher margins for all banks in the market as banks exploit their market power.

In order to measure the macroeconomic conditions in the banks' environment we use GDP growth, inflation, share of current account deficit in GDP and share of general government debt in GDP. Level of short term interest rates in the economy measures the stance of the economic policy. As an alternative, we estimate a specification that includes only yield spread on comparable government eurobonds from the observed countries and German government bond instead of a full set of macroeconomic indicators. This approach was motivated by findings presented in

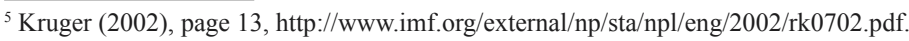


part of the literature on the determinants of emerging market bond spreads showing that the bond spreads include information about macroeconomic developments and other available information (Ferrucci, 2003; Alexopoulou, Bunda and Ferrando, 2009; Özatay, Özmen and Sahinbeyoglu, 2009). This specification also serves as the robustness check. Due to data availability, in this part of analysis time dimension for some countries is shortened.

\section{STYLIZED FACTS}

The median net interest margin for the sampled banks has been steadily decreasing during the studied period, indicating falling costs of financial intermediation. In the period prior to 2008 countries in the sample experienced relatively high rates of GDP growth combined with on average high capital inflows (measured by relatively high current account deficits) and were marked by high credit growth rates. Since 2008, as the crisis hit, GDP growth and capital inflows decreased significantly, together with credit activity (figure 1). Government debt to GDP increased from the beginning of the sample, especially after the onset of the crisis.

\section{Figure 1}

Net interest margin, GDP growth, government debt and current account deficit (\%)

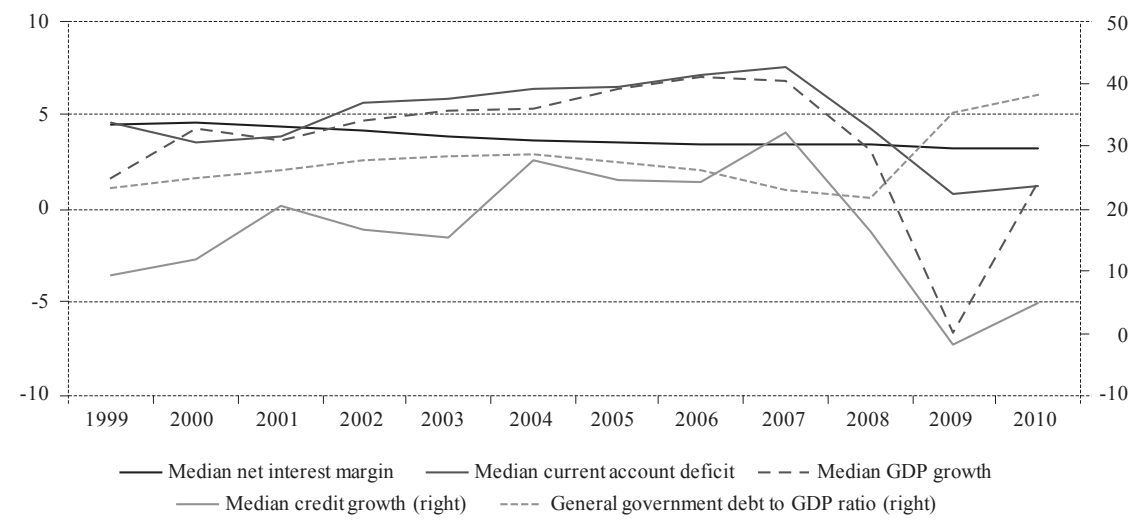

Source: Bankscope, Eurostat, own calculations.

Regarding bank specific variables, it should be noted that our sample starts in the year 1999, when the banking sector consolidation in CEE gained momentum (Kasman et al., 2010) and foreign investors had already become very important players in the CEE banking market. This process was marked by significant cost cutting and improved efficiency. The share of reserves for impaired loans, which was somewhat higher at the beginning of the sample (due to the Russian crisis and the still relatively underdeveloped bank management in the 1990s), gradually fell as assets grew. Similarly, the capital adequacy ratio for the median bank fell, implying on average, lower regulatory costs and reduced safety nets for the banks. 
After the onset of the crisis, reserves for impaired loans increased as the share of nonperforming loans rose significantly and capitalization increased as banks and regulators started building safety nets (figures 2 and 3 ).

\section{Figure 2}

Net interest margin, reserves for impaired loans and cost to income ratio (\%)

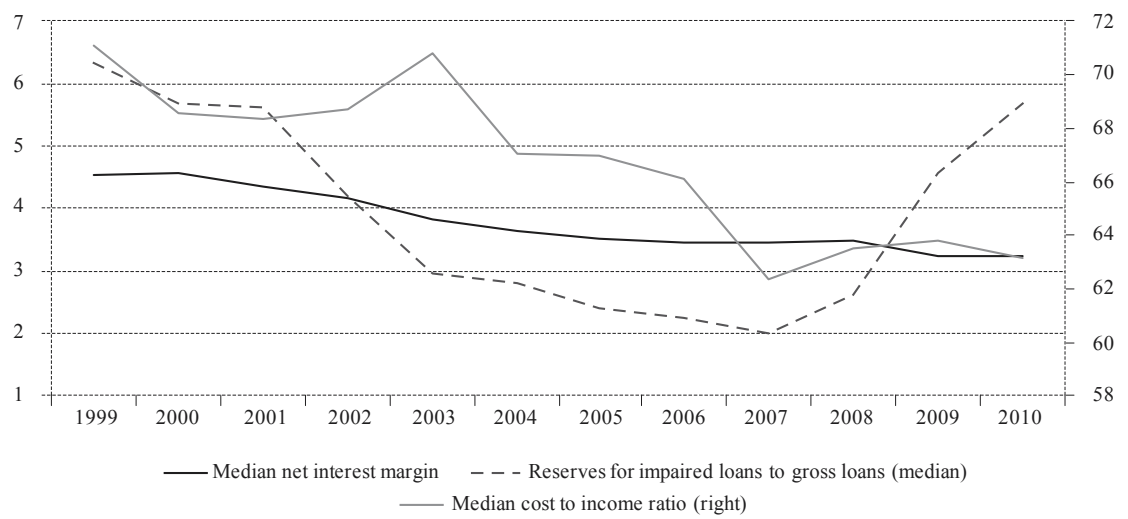

Source: Bankscope, own calculations.

\section{Figure 3}

Net interest margin and capital adequacy ratio (\%)

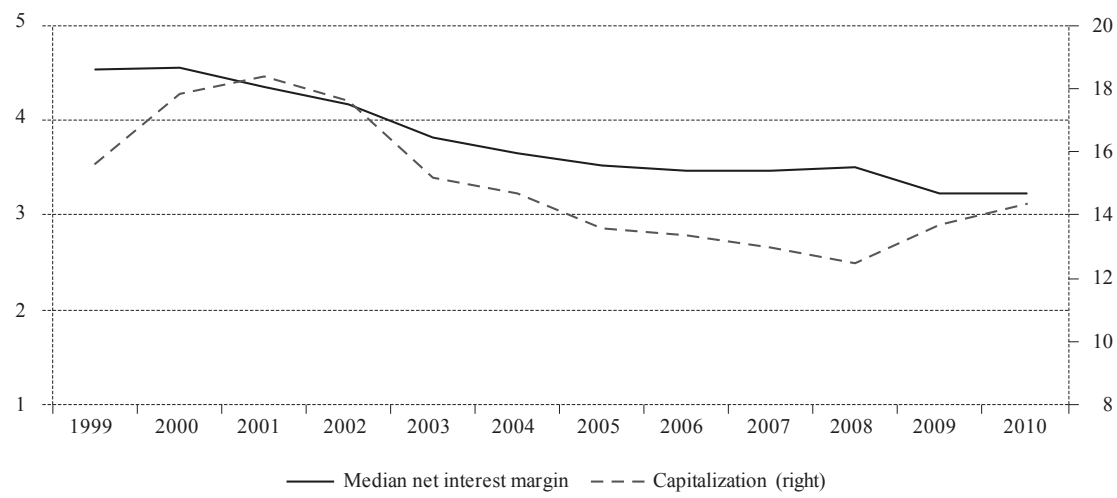

Source: Bankscope, own calculations.

In the pre-crisis period the standard deviation of net interest margin across banks was relatively low and increased significantly after it. This indicates that, after a period of relative tranquility in the CEE banking industry, the ongoing financial crisis and recession brought about diversification as a result of an accumulation of risks that were not properly managed (figure 4). 
Figure 4

Standard deviation of net interest margin (\%)

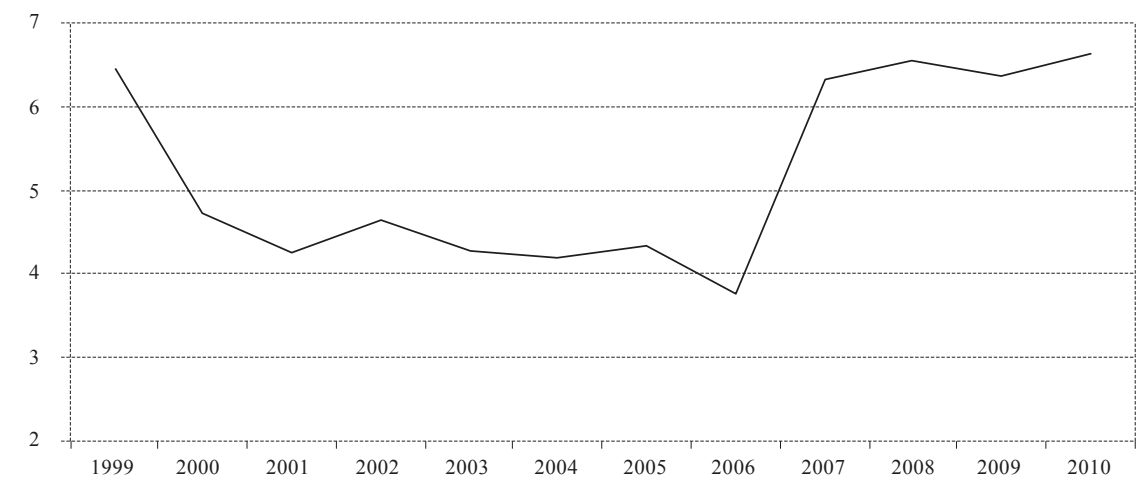

Source: Bankscope; own calculations.

Finally, the share of non-interest income in gross revenue for the CEE banks fell significantly in the post 2008 period. This is probably due to the fact that various charges were linked with the credit granting process (figure 5) and as the credit activity dried out, this had an impact on non-interest income as well.

\section{Figure 5}

Credit growth and noninterest income to gross revenue (\%)

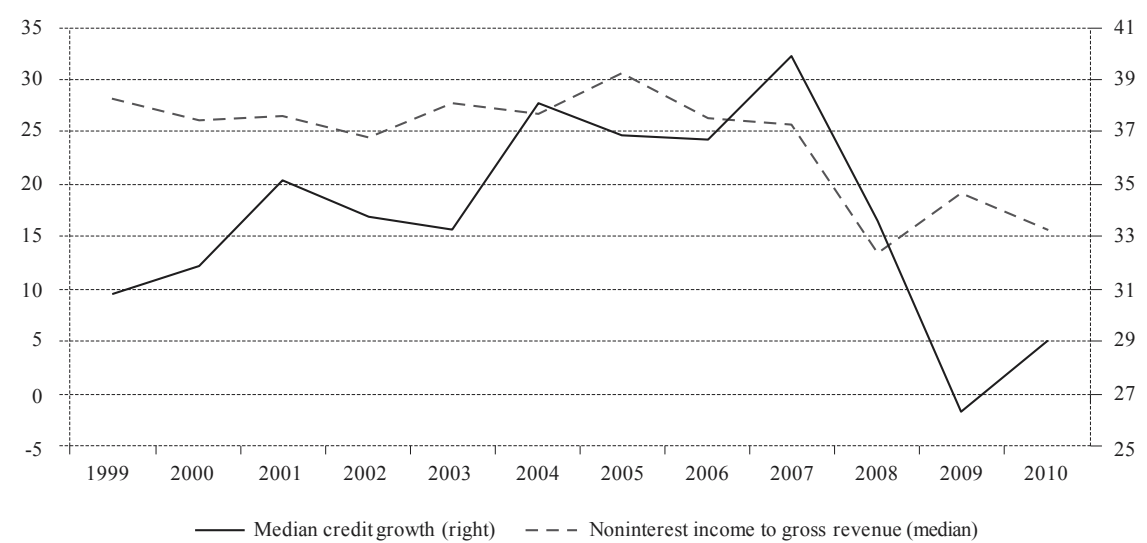

Source: Bankscope; own calculations.

Based on these observations, the main hypotheses on the determinants of interest rate margins can be formulated as follows:

1) Favourable macroeconomic conditions and high capital inflows are correlated with lower net interest margins. 
2) Among bank specific variables, increased efficiency, decreasing capitalization and reserves for impaired loans are linked with lower net interest margins.

\section{METHODOLOGY}

The data generating process is assumed to be defined by:

$$
\begin{aligned}
& y_{i, t}=\alpha y_{i, t-1}+x_{i t}^{\prime} \beta+\varepsilon_{i, t} \\
& \varepsilon_{i, t}=\mu_{i}+v_{i, t} \\
& E\left[\mu_{i}\right]=E\left[v_{i, t}\right]=E\left[\mu_{i} v_{i, t}\right]=0 .
\end{aligned}
$$

The subscripts $i$ and $t$ are for the bank and year respectively.

Net interest margin is represented by $y_{i^{\prime} t}, x$ is the matrix of explanatory variables presented in table 1 . Some variables in matrix $x$ are country specific, i.e. they are the same for all banks from a given country. The error term has two orthogonal components, fixed effects $\mu_{i}$ and idiosyncratic shocks $v_{i} t^{\prime}$

The combination of a relatively short time period, the use of a lagged dependent variable, bank specific fixed effects and possible endogeneity problems with bank specific variables make the use of least squares unfeasible as the estimates are not consistent. Using OLS with fixed effects and lagged dependent variable gives rise to dynamic panel bias (see Nickel, 1981; or Roodman, 2006) because the lagged dependent variable is correlated with error term by construction. ${ }^{6}$

Our data set has a large cross section and relatively small time dimension, so the problems mentioned above can be solved by using the Arellano and Bover (1995) system GMM estimator. This estimator uses lagged levels of dependent variable and orthogonal deviations of other endogenous variables as instruments. By using orthogonal transformations it allows for the use of a lagged dependent variable as an explanatory variable. Consequently, we estimate the equation (1) using Arellano and Bover (1995) system GMM estimator. We treat all bank specific variables from table 1 as endogenous and instrument them with their orthogonal transformations.

\section{EMPIRICAL RESULTS AND ROBUSTNESS}

The estimated model is

$$
\begin{aligned}
& y_{i, t}=\alpha y_{i, t-1}+x_{i t}^{\prime} \cdot \beta_{B S}+w_{i t}^{\prime} \cdot \beta_{B M}+z_{i t}^{\prime} \cdot \beta_{M}+\varepsilon_{i, t} \\
& \varepsilon_{i, t}=\mu_{i}+t_{t}+v_{i, t}
\end{aligned}
$$

\footnotetext{
${ }^{6}$ Modifying an example of Roodman (2006), consider a company $\times$ year panel and a firm that has a large negative temporary shock to its employment in one period. As a result fixed effect for this firm for all years will be lower. If the shock happens in time $t$, in time $t+1$ the lagged dependent variable is lower together with fixed effect. This positive correlation between error term and regressor violates the consistency assumption by inflating the coefficient estimate for lagged dependent variable.
} 
The three vectors of variables represent the banks-specific $\left.\left(x_{i},\right)\right)$, banking marketspecific $\left(w_{i, t}\right)$ and macroeconomic variables $\left(z_{i}, t\right)$ described in table 1 and $y_{i, t}$, represents the net interest margin. Subscripts $i$ and $t$ are for $i$-th bank and $t$-th time period. Error term has a bank-specific $\left(\mu_{i}\right)$ and a time-specific part $\left(t_{t}\right)$, which are controlled for in the estimation. ${ }^{7}$ Finally, the dot operator (.) represents element by element multiplication.

The estimation results are presented in table 2. Equation 2 is in the first step estimated for the whole sample period (specification 1). As a robustness test, we perform structural break tests by using the form of Chow test for GMM estimated equations, the Andrews and Fair (1988) test. The existence of a possible break is tested in 2007 and 2008. For both years the test finds insufficient evidence against hypothesis $\mathrm{H}_{0}$ of parameter stability. ${ }^{8}$ To test for the possible breaks in some specific parameters we use a dummy variable named CRISIS which equals 1 in years 2008, 2009 and 2010 and zero otherwise.

The results of our baseline specification show that there is a relatively high persistence of net interest margin across time, as the coefficient with the lagged net interest margin is relatively high and significant (specification 1, table 2). This justifies the inclusion of lagged values of net interest margin in the estimated regressions.

All included macroeconomic indicators proved to be statistically significantly linked to the net interest margin, meaning that the environment in which banks operate significantly influences their performance. The link between GDP growth and net interest margin is positive, implying that periods of high growth can result in higher net interest margins due to more intense credit activity and better loan quality, as noted by Claeys and Vander Vennet (2004) (it should be noted though that the $p$ value for the GDP growth is 0.051 in specification 1 and that is insignificant at standard levels in specification 2). According to the presented results, the relatively big capital inflows that CEE countries experienced in the observed period (measured by current account deficit) had a positive effect on the cost of financial intermediation. The results show that higher capital inflows were linked with on average a lower net interest margin charged by the banks. In contrast, the correlation of general government debt and net interest margin is on average positive, implying that government debt accumulation increases the net interest margin, probably due to increased macroeconomic risks and the potential unsustainability. Inflation is positively correlated with net interest margin, in line with the findings in the studied literature, while the relation between interest rates and interest margins is negative.

\footnotetext{
${ }^{7}$ The significance of time specific fixed effects was tested using the Wald test after GMM estimation. The significance of bank specific fixed effects was done applying the Hausman test after fixed effects regression. Both tests show strong evidence against the null hypothesis which states that the effects are equal to 0 .

${ }^{8}$ Test value for 2007 is 0.082 and for 20080.074 , which is much less than the $5 \%$ or $10 \%$ critical value for Chi-squared distribution.
} 
TABLE 2

Estimation results

Equation name

Specifications

\begin{tabular}{|c|c|c|c|c|c|}
\hline & 1 & 2 & 3 & 4 & 5 \\
\hline $\begin{array}{l}\text { Dependent } \\
\text { variable }\end{array}$ & \multicolumn{5}{|c|}{ Net interest margin } \\
\hline $\begin{array}{l}\text { Net interest margin } \\
\text { lagged (-1) }\end{array}$ & $\begin{array}{l}0.5046 \\
(0.0200)^{* *}\end{array}$ & $\begin{array}{l}0.4411 \\
(0.0230)^{* *}\end{array}$ & $\begin{array}{l}0.5005 \\
(0.0139)^{* *}\end{array}$ & $\begin{array}{l}0.5842 \\
(0.0240)^{* *}\end{array}$ & $\begin{array}{c}0.4361 \\
(0.0333)^{* *}\end{array}$ \\
\hline $\begin{array}{l}\text { Cost to income } \\
\text { ratio }\end{array}$ & $\begin{array}{l}-0.0060 \\
(0.0016)^{* *}\end{array}$ & $\begin{array}{l}-0.0047 \\
(0.0015)^{* *}\end{array}$ & $\begin{array}{l}-0.0045 \\
(0.0016)^{* *}\end{array}$ & $\begin{array}{l}-0.0071 \\
(0.0017)^{* *}\end{array}$ & $\begin{array}{c}0.0031 \\
(0.0016)\end{array}$ \\
\hline Total capital ratio & $\begin{array}{l}-0.0044 \\
(0.0032)\end{array}$ & $\begin{array}{l}-0.0078 \\
(0.0023)^{* *}\end{array}$ & $\begin{array}{l}-0.0012 \\
(0.0020)\end{array}$ & $\begin{array}{l}0.0108 \\
(0.0039)^{* *}\end{array}$ & $\begin{array}{c}0.0347 \\
(0.0091)^{* *}\end{array}$ \\
\hline $\begin{array}{l}\text { Ratio of } \\
\text { noninterest revenue } \\
\text { to gross revenue } \\
\end{array}$ & $\begin{array}{l}-0.0221 \\
(0.0027)^{* *}\end{array}$ & $\begin{array}{l}-0.0221 \\
(0.0026)^{* *}\end{array}$ & $\begin{array}{l}-0.0176 \\
(0.0025)^{* *}\end{array}$ & $\begin{array}{l}-0.0224 \\
(0.0028)^{* *}\end{array}$ & $\begin{array}{l}-0.0304 \\
(0.0031)^{* *}\end{array}$ \\
\hline $\begin{array}{l}\text { Ratio of loans to } \\
\text { customer deposits }\end{array}$ & $\begin{array}{c}0.0005 \\
(0.0006)\end{array}$ & $\begin{array}{c}0.0014 \\
(0.0007)\end{array}$ & $\begin{array}{c}0.0007 \\
(0.0004)\end{array}$ & $\begin{array}{l}0.0020 \\
(0.0007)^{* *}\end{array}$ & $\begin{array}{c}0.0026 \\
(0.0007)^{* *}\end{array}$ \\
\hline $\begin{array}{l}\text { Ratio of reserves } \\
\text { for impaired loans } \\
\text { to impaired loans }\end{array}$ & $\begin{array}{l}-0.0245 \\
(0.0059)^{* *}\end{array}$ & $\begin{array}{l}-0.0310 \\
(0.0055)^{* *}\end{array}$ & $\begin{array}{l}-0.0276 \\
(0.0044)^{* *}\end{array}$ & $\begin{array}{l}-0.0244 \\
(0.0067)^{* *}\end{array}$ & $\begin{array}{l}-0.0404 \\
(0.0089)^{* *}\end{array}$ \\
\hline $\begin{array}{l}3 \text { month money } \\
\text { market interest rate }\end{array}$ & $\begin{array}{l}-0.1231 \\
(0.0171)^{* *}\end{array}$ & $\begin{array}{l}-0.0962 \\
(0.0181)^{* *}\end{array}$ & & & \\
\hline GDP growth & $\begin{array}{c}0.0285 \\
(0.0146)\end{array}$ & $\begin{array}{c}0.0250 \\
(0.0177) \\
\end{array}$ & & & \\
\hline Inflation & $\begin{array}{l}0.1156 \\
(0.0184)^{* *}\end{array}$ & $\begin{array}{l}0.1138 \\
(0.0174)^{* *}\end{array}$ & & & \\
\hline Current account & $\begin{array}{c}0.0848 \\
(0.0120)^{* *} \\
\end{array}$ & $\begin{array}{c}0.0890 \\
(0.0126)^{* *}\end{array}$ & & & \\
\hline Government debt & $\begin{array}{l}0.0285 \\
(0.0077)^{* *}\end{array}$ & $\begin{array}{l}0.0406 \\
(0.0091)^{* *}\end{array}$ & & & \\
\hline Concentration & $\begin{array}{c}0.0227 \\
(0.0136)\end{array}$ & $\begin{array}{l}-0.0005 \\
(0.0131)\end{array}$ & $\begin{array}{l}0.0693 \\
(0.0083)^{* *}\end{array}$ & $\begin{array}{l}-0.1173 \\
(0.0135)^{* *}\end{array}$ & $\begin{array}{c}0.0039 \\
(0.0120)\end{array}$ \\
\hline $\begin{array}{l}\text { Total capital ratio } * \\
\text { Crisis }\end{array}$ & & $\begin{array}{l}-0.1154 \\
(0.0159)^{* *}\end{array}$ & $\begin{array}{l}-0.1175 \\
(0.1174)^{* *}\end{array}$ & $\begin{array}{l}-0.2539 \\
(0.0205)^{* *}\end{array}$ & $\begin{array}{l}-0.1196 \\
(0.0140)^{* *}\end{array}$ \\
\hline Country spread & & & & $\begin{array}{l}0.0048 \\
(0.0005)^{* *}\end{array}$ & $\begin{array}{l}0.0027 \\
(0.0006)^{* *}\end{array}$ \\
\hline Regulatory cost & & & & & $\begin{array}{l}-0.0060 \\
(0.0047)\end{array}$ \\
\hline Time dummies & Yes & Yes & Yes & Yes & Yes \\
\hline Observations & 823 & 824 & 858 & 640 & 506 \\
\hline Banks & 152 & 152 & 153 & 131 & 122 \\
\hline Periods & 12 & 12 & 12 & 10 & 8 \\
\hline Hansen J statistics & 84.49 & 76.65 & 81.38 & 78.87 & 71.05 \\
\hline $\mathrm{p}$ value & 0.1307 & 0.2738 & 0.2873 & 0.2707 & 0.2547 \\
\hline
\end{tabular}

Notes: Robust standard errors are in brackets, all estimators are of panel GMM system types, Arellano and Bover (1995). Hansen J statistics and $p$ value are for Hansen test for overidentifying restrictions.

* Significance at 5\%; ** significance at $1 \%$.

Source: Own calculations. 
Among the bank-specific variables, most of the coefficients have the expected signs. The cost to income ratio is negatively correlated with net interest margin, implying that relatively less efficient banks marked by higher cost to income ratio had higher net interest margins, as concluded by the most of the analysed authors (table A1). The ratio of non-interest income to gross revenue is significant and negative suggesting that banks with a higher share of non-interest income in their gross revenues charged lower margins for loans granted and collected additional revenue through various charges connected to credit activity. Reserves for impaired loans are significantly negatively correlated with net interest margin. This most probably stems from the fact that the banks are not allowed to accrue interest on bad loans. The only unexpected result in this specification is that the capitalization ratio is not significant. As many other researchers find evidence of this link (i.e. Claeys and Vander Vennet, 2008 for the CEE countries), we test for the potential structural break in this relationship. By interacting the aforementioned crisis dummy with total capitalization ratio we get specific estimates for the partial correlation of capitalization with net interest margin in the pre-crisis and crisis periods (specification 2, table 2). The results show that there is a structural change in the relationship between total capitalization ratio and net interest margin. The partial correlation between total capitalization ratio and net interest margin is negative and much higher in the crisis period, implying that increasing capital during the crisis can be very costly for the bank.

As robustness check we estimated several modified specifications. In the third specification macro variables are excluded (specification 3, table 2), while in the fourth specification all macro variables are replaced with the yield spread on government bonds acting as synthetic macro variable (specification 4). In this specification Slovenia and Estonia fall out of the sample because there are no comparable data on the yield spreads available for these countries. Also, the data for Slovakia have missing values in years 2009 and 2010. The fifth specification includes a regulatory cost variable (specification 5) that is also not available for Slovenia and Estonia and has missing values for the majority of countries in the period before 2003. In this shortened sample (specifications 4 and 5) the ratio of loans to customer deposits becomes significant, implying that banks that had fewer deposits in their funding mix charged a somewhat higher margin. Additionally, the coefficient on the total capitalization ratio in the pre-crisis period in these specifications (specifications 4 and 5) is positive, albeit the value is small. Finally, we should note the concentration ratio is significant in some specifications (specifications 3 and 4) but it is not robust as it changes signs.

Regarding additional regressors in specifications 4 and 5, two results seek special attention. Firstly, the yield spread variable included in specification 4 shows that increased country risk is linked to higher cost of financial intermediation. This corroborates results of other specifications where macroeconomic risks are on average positively correlated with net interest margin (specifications 1 and 2). 
Secondly, the correlation of regulatory costs and net interest margin is negative (specification 5), however this relationship is not statistically significant.

We have also performed robustness test that splits sample in two parts: highly euroized economies (Bulgaria, Croatia, Estonia, Hungary, Latvia, Lithuania and Slovenia prior to eurozone entry) vs. others. The Andrews-Fair (1988) test statistic is 16.62 , which is less that critical value of 37.65 for $5 \%$ significance level.

In sum, we can conclude that the estimation results showed to be robust in these tests. The statistical significance of the coefficients remains the same across specifications and their sizes do not change significantly.

\section{CONCLUSION}

In this research we analyzed the main net interest margin determinants of banks operating in Central and Eastern European countries from 1999 to 2010. We used the Arellano and Bover (1995) system GMM estimator which is robust to endogeneity problems and allows for the inclusion of a lagged dependent variable together with fixed effects to control for unobserved heterogeneity.

The results imply there have been several main drivers of decline in net interest margins in CEE in the pre-crisis period. Prior to 2008 the net interest margins declined primarily due to strong capital inflows, a stable macroeconomic environment (low inflation and low short term interest rates) and a fall in the share of nonperforming loans in the balance sheets of the banks. On the other hand, the economic boom (relatively high GDP growth rates) and rising government debt allowed banks to charge somewhat higher margins due to high demand for credit. In the crisis period, rapidly increasing government debt and the associated increase in macroeconomic risks together with declining capital inflows were propping up margins while other factors such as low demand (due to weak economic performance), higher capitalization and significantly increased share of non-performing loans pressured banks' margins down.

The results of the estimation also show that throughout the studied period increased efficiency in the CEE banking sector has led to lower margins. The important implication of this result for banks' management is that the banks which are not able to lower their costs (and margins) will lose their competitive position and subsequently market share.

When looking at the possible manoeuvring space for policy makers' actions that could affect the costs of financial intermediation and in turn interest rates, and therefore indirectly support economic activity our results indicate that a stable macroeconomic environment and significant capital inflows support lower net interest margins. On the other hand increasing government debt and associated macroeconomic risks are linked with higher margins. Finally, in line with general 
opinion, pressures by the regulators to increase capital during the crisis will result in lower banks' operating profitability, which might make some banks business models unviable. 
20

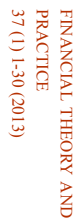

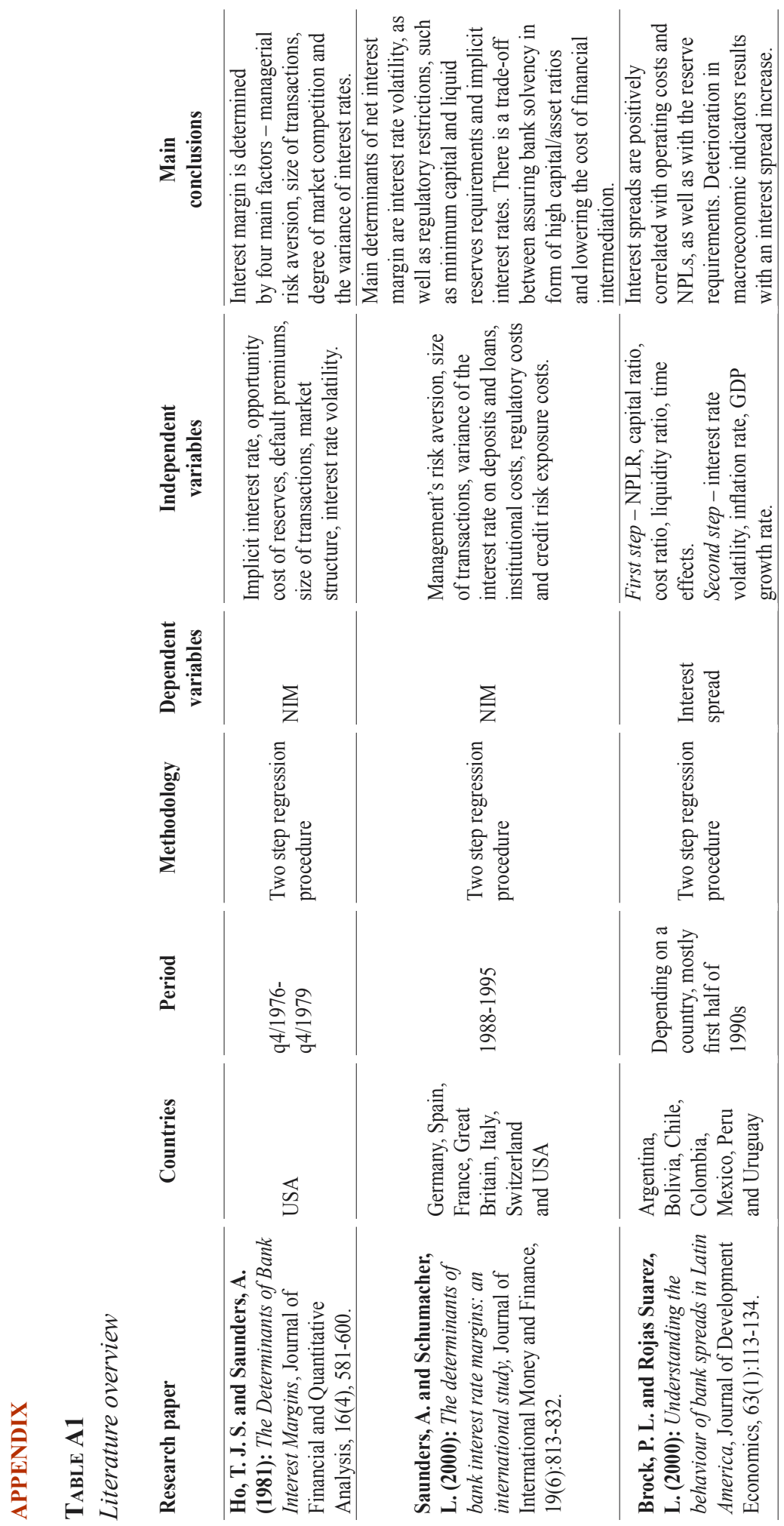




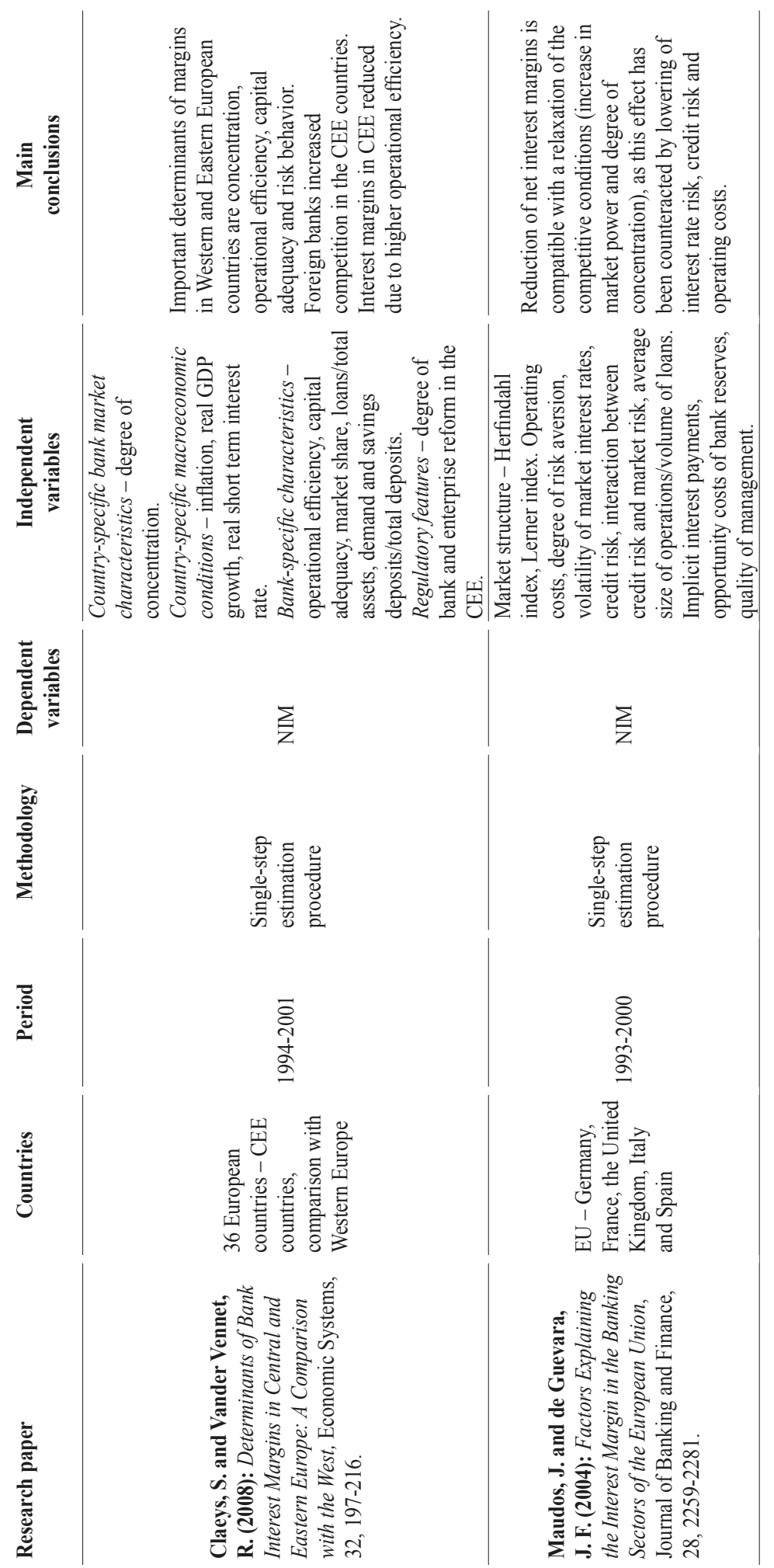

21
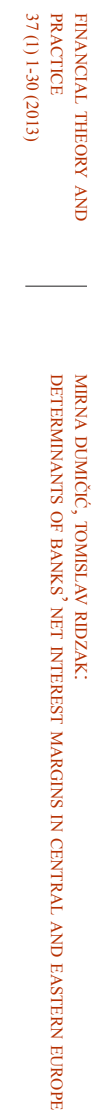


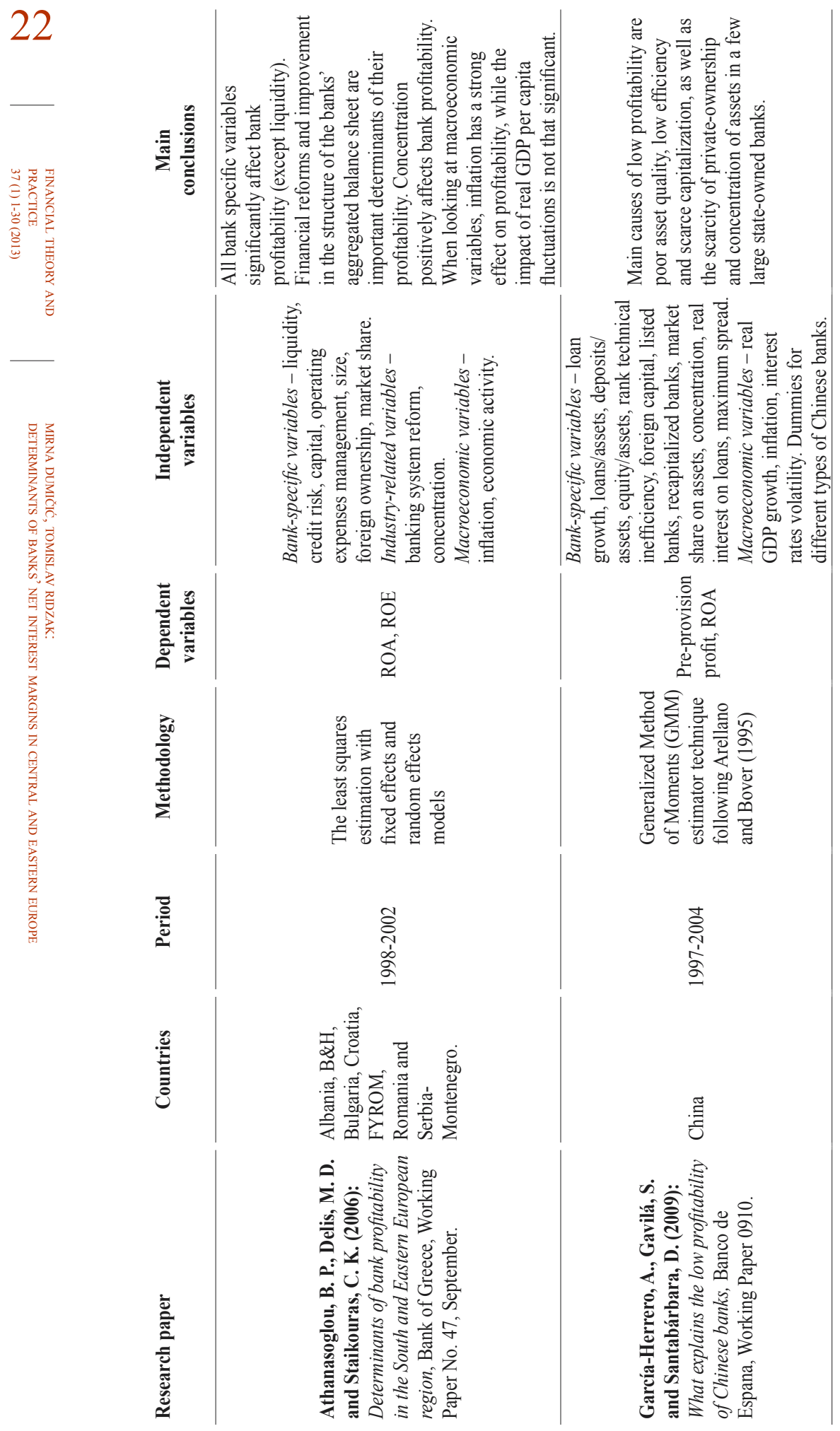



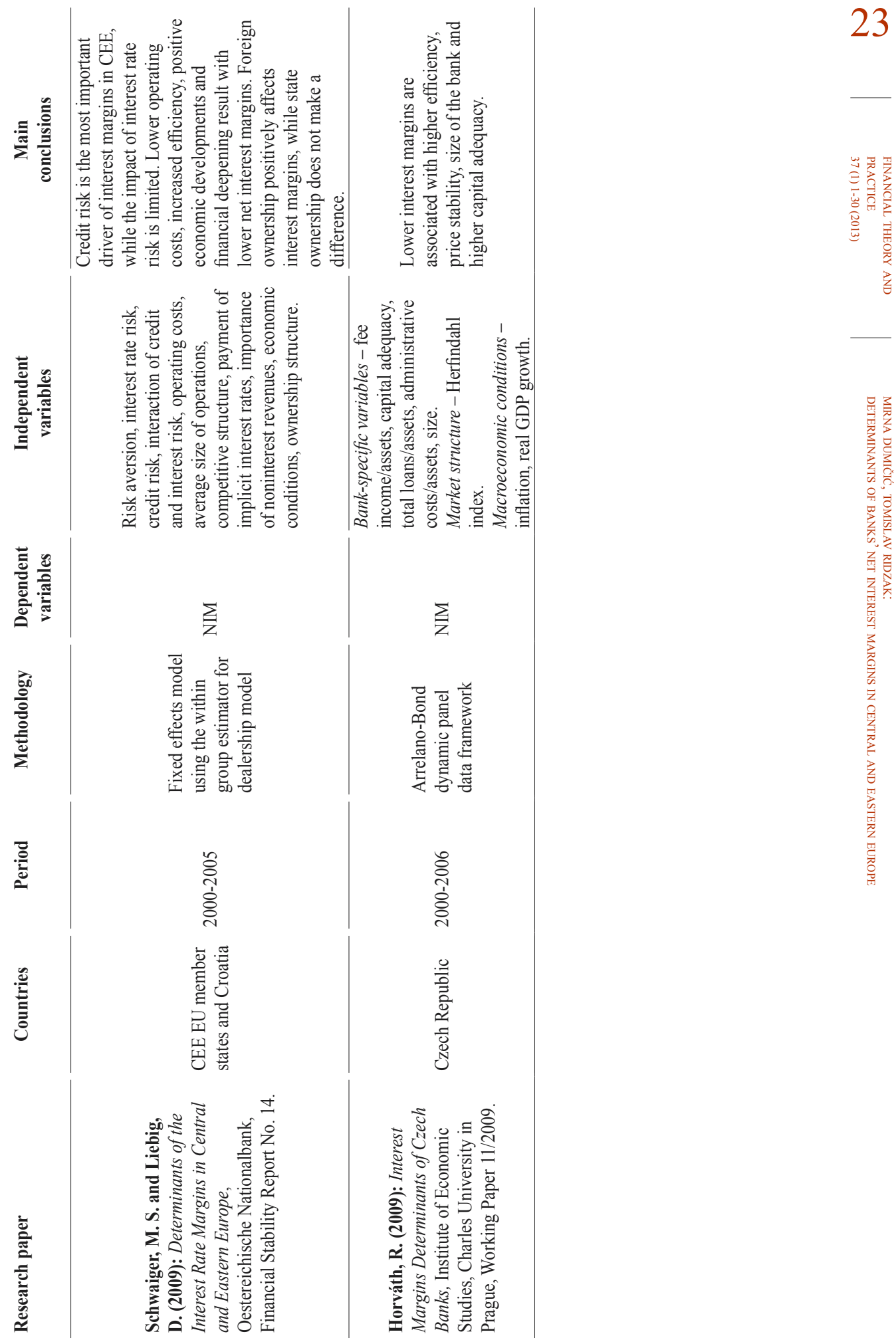


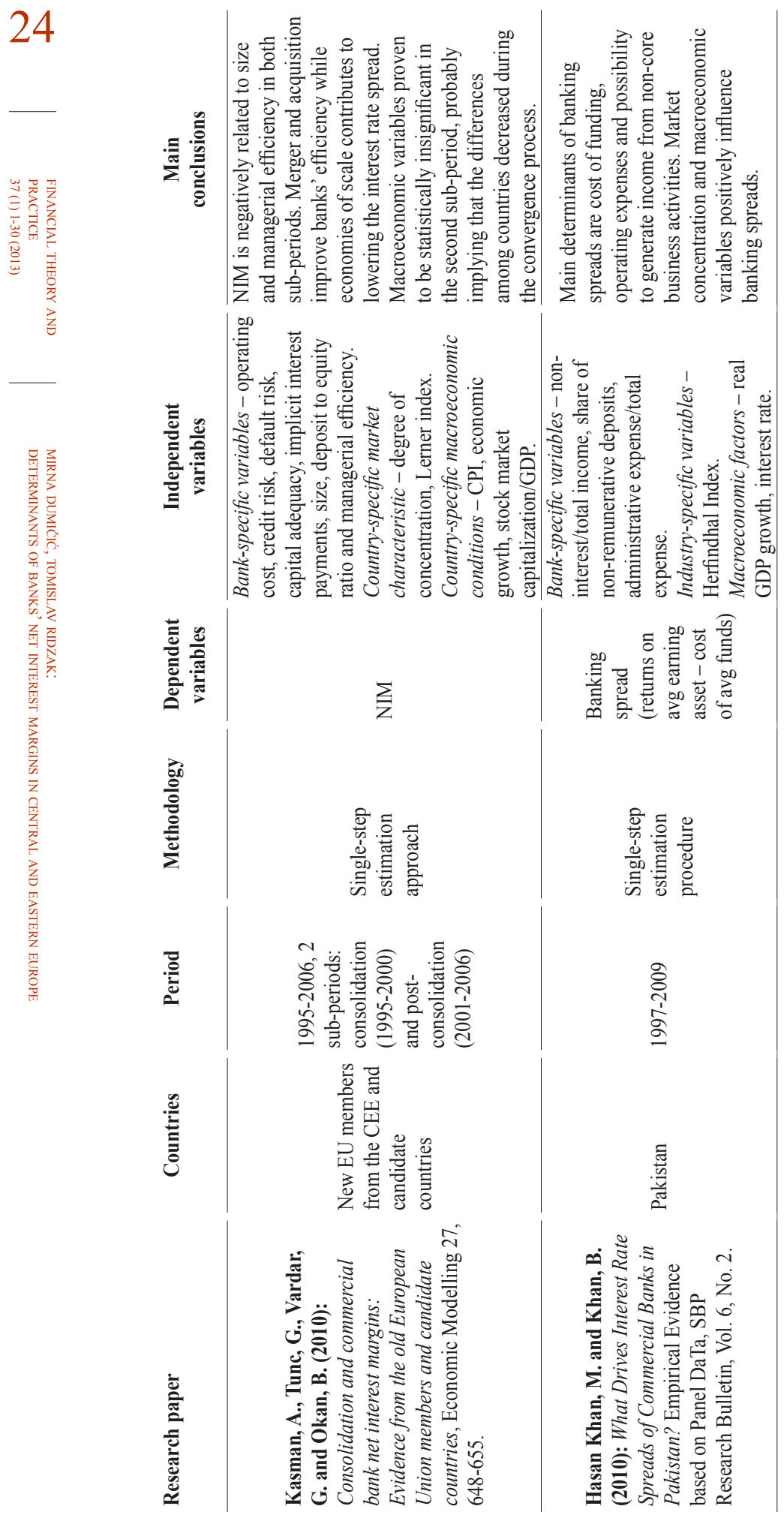



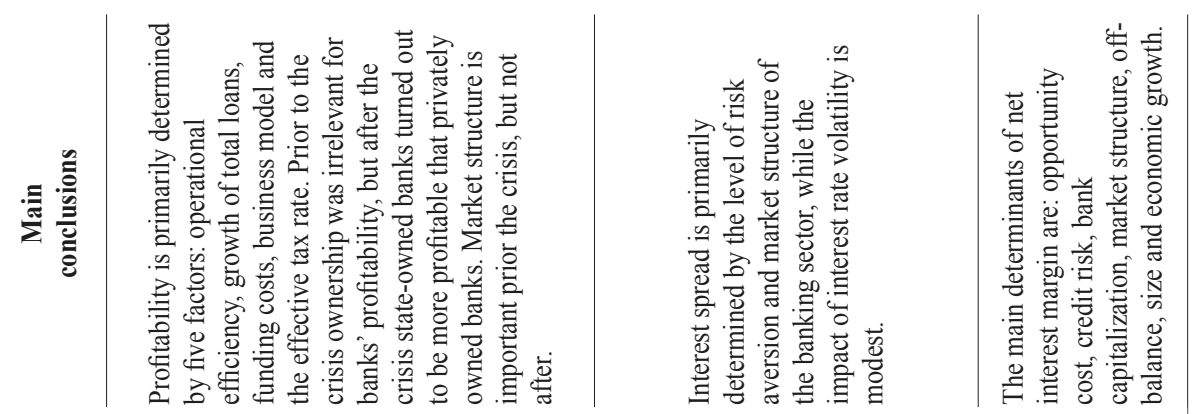

25

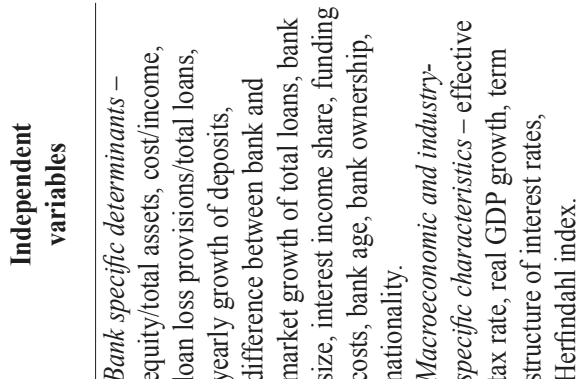

|
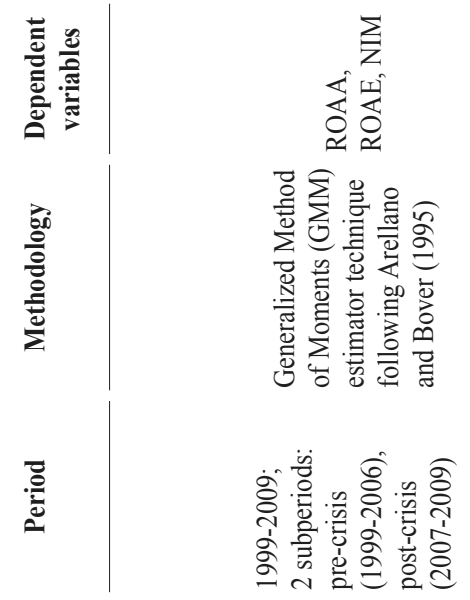

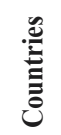
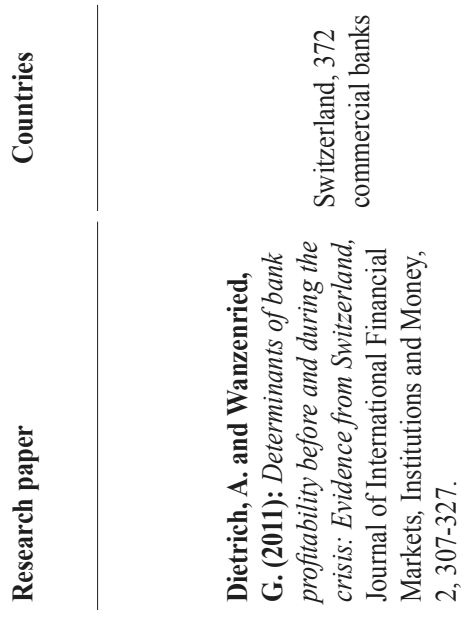

苞芯

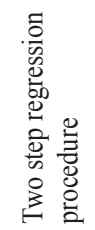

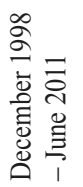

䓂

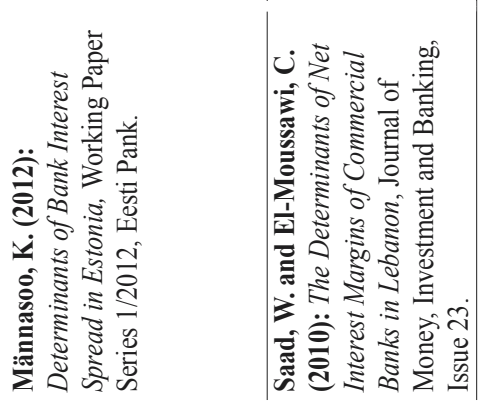

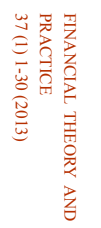

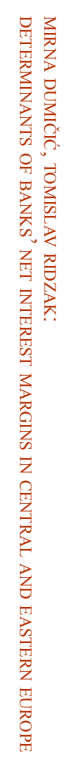




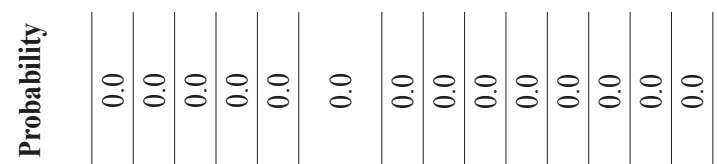
竞

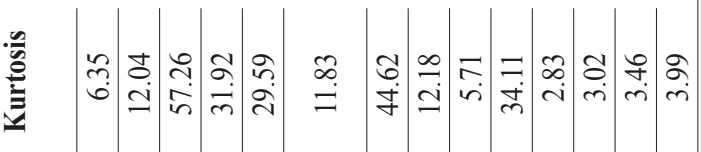

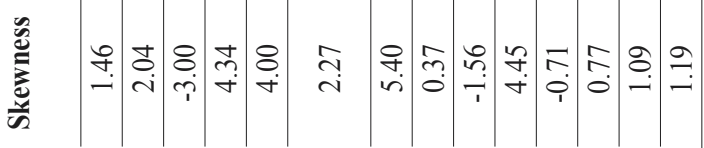

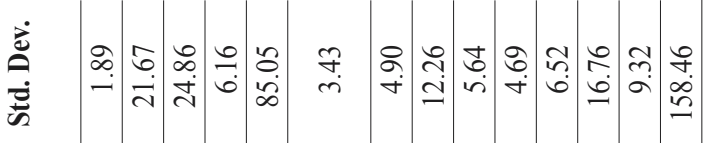

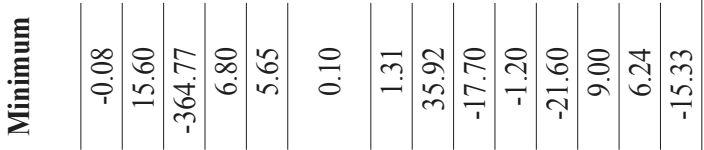

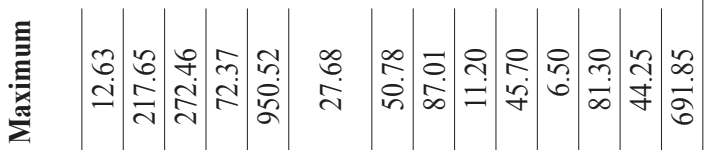
方

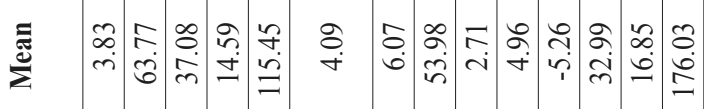

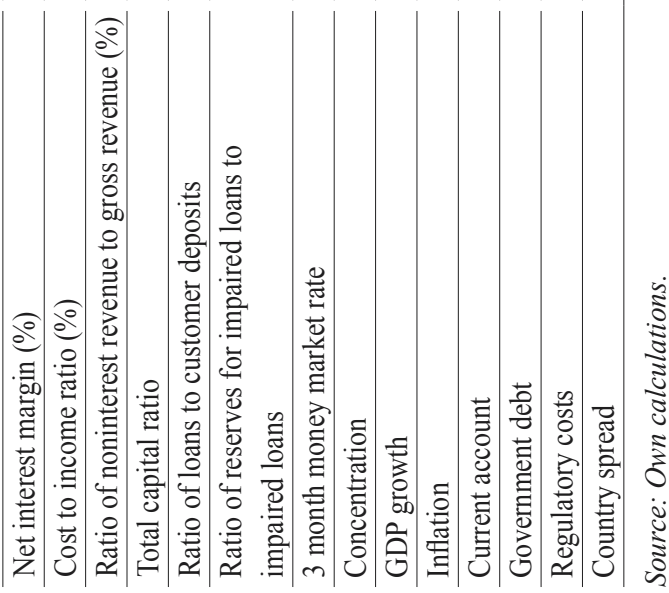


Table A3

Panel unit root test results

\section{Variable name}

\begin{tabular}{|c|c|c|}
\hline 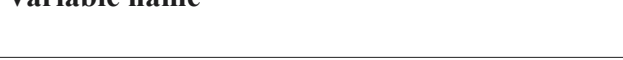 & (2002) & Shin (2003) \\
\hline Net interest margin $(\%)$ & $\mathrm{I}(0)$ & $\mathrm{I}(0)$ \\
\hline Cost to income ratio $(\%)$ & $\mathrm{I}(0)$ & $\mathrm{I}(0)$ \\
\hline Ratio of noninterest revenue to gross revenue (\%) & $\mathrm{I}(0)$ & $\mathrm{I}(0)$ \\
\hline Total capital ratio & $\mathrm{I}(0)$ & $\mathrm{I}(0)$ \\
\hline Ratio of loans to customer deposits & $\mathrm{I}(0)$ & $\mathrm{I}(0)$ \\
\hline Ratio of reserves for impaired loans to impaired loans & $\mathrm{I}(0)$ & $\mathrm{I}(1)$ \\
\hline Concentration & $\mathrm{I}(0)$ & $\mathrm{I}(0)$ \\
\hline 3 month money market rate & $\mathrm{I}(0)$ & $\mathrm{I}(0)$ \\
\hline GDP growth & $\mathrm{I}(0)$ & $\mathrm{I}(0)$ \\
\hline Inflation & $\mathrm{I}(0)$ & $\mathrm{I}(0)$ \\
\hline Current account & $\mathrm{I}(1)$ & $\mathrm{I}(0)$ \\
\hline Government debt & $\mathrm{I}(0)$ & $\mathrm{I}(1)$ \\
\hline Growth rate of gross loans & $\mathrm{I}(0)$ & $\mathrm{I}(0)$ \\
\hline Regulatory cost & $\mathrm{I}(0)$ & $\mathrm{I}(0)$ \\
\hline
\end{tabular}

(2002)

\section{Levin, Liu \& Chu Im, Pesaran and}

Source: Own calculations. 
1. Alexopoulou, I., Bunda, I. and Ferrando, A., 2009. Determinants of government bond spreads in new EU countries. ECB Working Paper Series, No. 1101 [online]. Available at: <www.ecb.int/pub/pdf/scpwps/ecbwp1101.pdf>.

2. Andrews, D. W. K. and Fair, R. C., 1988. Inference in nonlinear econometric models with structural change. Review of Economic Studies, 55(4), pp. 615639. doi: $10.2307 / 2297408$

3. Arghyrou, M. G., Gregoriou, A. and Kontonikas, A., 2009. Do real interest rates converge? Evidence from the European Union. Journal of International Financial Markets, Institutions and Money, 19(3), pp. 447-460. doi: 10.1016/j. intfin.2008.05.004

4. Athanasoglou, B. P., Delis, M. D. and Staikouras, C. K., 2006. Determinants of bank profitability in the South and Eastern European region. Bank of Greece Working Paper, (47). Athene: Bank of Greece.

5. Brock, P. L. and Rojas Suarez, L., 2000. Understanding the behaviour of bank spreads in Latin America. Journal of Development Economics, 63(1), pp. 113 134. doi: 10.1016/S0304-3878(00)00102-4

6. Claeys, S. and Vander Vennet, R., 2008. Determinants of Bank Interest Margins in Central and Eastern Europe: A Comparison with the West. Economic Systems, 32(2), pp. 197-216. doi: 10.1016/j.ecosys.2007.04.001

7. Coelli, T. J., 1996. Measurement of Total Factor Productivity Growth and Biases in Technological Change in Western Australian Agriculture. Journal of Applied Econometrics, 11(1), pp. 77-91. doi: 10.1002/(SICI)1099-1255 (199601)11:1<77::AID-JAE370>3.0.CO;2-H

8. De Haas, R. and Van Lelyveld, I., 2010. Internal capital markets and lending by multinational bank subsidiaries. Journal of Financial Intermediation, 19(1), pp. 1-25. doi: 10.1016/j.jfi.2009.02.001

9. Dietrich, A. and Wanzenried, G., 2011. Determinants of bank profitability before and during the crisis: Evidence from Switzerland. Journal of International Financial Markets, Institutions and Money, 21(3), pp. 307-327. doi: 10.1016/j.intfin.2010.11.002

10. Feige, E. L., 2003. The Dynamics in Currency Substitution, Asset Substitution and De facto Dollarization and Eurization in Transition Countries. Dubrovnik Economic Conference, June.

11. Ferrucci, G., 2003. Empirical determinants of emerging market economies' sovereign bond spreads. Bank of England, Working Paper, No. 205.

12. Fonseca, A. R. and González, F., 2008. Cross-country determinants of bank income smoothing by managing loan-loss provisions. Journal of Banking and Finance, 32(2), pp. 217-228. doi: 10.1016/j.jbankfin.2007.02.012

13. Gabrieli, S., 2010. The functioning of the European interbank market during the 2007-08 financial crisis. CEIS Research Paper 158. Tor Vergata University, CEIS, revised 28 May. 
14. García-Herrero, A., Gavilá, S. and Santabárbara, D., 2009. What explains the low profitability of Chinese banks. Banco de Espana, Working Paper 0910.

15. Hamadi, H. and Awdeh, A., 2012. The Determinants of Bank Net Interest Margin: Evidence from the Lebanese Banking Sector. Journal of Money, Investment and Banking, (23), pp. 85-98.

16. Hasan Khan, M. and Khan, B., 2010. What Drives Interest Rate Spreads of Commercial Banks in Pakistan? Empirical Evidence based on Panel Data. SBP Research Bulletin, 6(2), pp. 15-36.

17. Heider, F., Hoerova, M. and Holthausen, C., 2009. Liquidity hoarding and interbank market spreads: the role of counterparty risk. European Banking Center Discussion Paper, No. 2009-11S.

18. Ho, T. J. S. and Saunders, A., 1981. The Determinants of Bank Interest Margins. Journal of Financial and Quantitative Analysis, 16(4), pp. 581-600. doi: $10.2307 / 2330377$

19. Horváth, R. 2009. The Determinants of the Interest Rate Margins of Czech Banks. Czech Journal of Economics and Finance (Finance a uver), 59(2), pp. 128-136.

20. Im, K., Pesaran, H. and Shin, Y., 2003. Testing for unit roots in heterogeneous panels. Journal of Econometrics, 115(1), pp. 53-74. doi: 10.1016/S03044076(03)00092-7

21. IMF, 2009. Republic of Croatia: 2009 Article IV Consultation - Staff Report; Public Information Notice on the Executive Board Discussion; and Statement by the Executive Director for the Republic of Croatia. IMF Country Report No. 09/185, June.

22. Kasman, A. et al., 2010. Consolidation and commercial bank net interest margins: Evidence from the old European Union members and candidate countries. Economic Modeling, 27(3), pp. 648-655. doi: 10.1016/j.econmod. 2010.01.004

23. Kruger, R., 2002. International Standards for Impairment and Provisions and their Implications for Financial Soundness Indicators (FSIs). IMF mimeo.

24. Levin, A., Lin, C. and Chu, C., 2002. Unit root tests in panel data: Asymptotic and finite-sample properties. Journal of Econometrics, 108(1), pp. 1-24. doi: 10.1016/S0304-4076(01)00098-7

25. Männasoo, K., 2012. Determinants of Bank Interest Spread in Estonia. Eesti Pank, Working Paper Series, 1/2012.

26. Maudos, J. and de Guevara J. F., 2004. Factors Explaining the Interest Margin in the Banking Sectors of the European Union. Journal of Banking and Finance, 28(9), pp. 2259-2281. doi: 10.1016/j.jbankfin.2003.09.004

27. Nickell, S., 1981. Biases in dynamic models with fixed effects. Econometrica 49(6), pp. 1417-1426. doi: 10.2307/1911408 
28. Özatay, F., Özmen, E. and Sahinbeyoglu, G., 2009. Emerging market sovereign spreads, global financial conditions and U.S. macroeconomic news. Economic Modelling, 26(2), pp. 526-531. doi: 10.1016/j.econmod.2008.10.008

29. Roodman, D., 2006. An introduction to "Difference" and "System" GMM in Stata. Center for Global Development, Working Paper, No. 103.

30. Saad, W. and El-Moussawi, C., 2010. The Determinants of Net Interest Margins of Commercial Banks in Lebanon. Journal of Money, Investment and Banking, (23), pp. 118-132.

31. Saunders, A. and Schumacher, L., 2000. The determinants of bank interest rate margins: an international study. Journal of International Money and Finance, 19(6), pp. 813-832. doi: 10.1016/S0261-5606(00)00033-4

32. Schwaiger, M. S. and Liebig, D., 2009. Determinants of the Interest Rate Margins in Central and Eastern Europe. Oestereichische Nationalbank, Financial Stability Report, No. 14.

33. Staikouras, C., Mamatzakis, E. and Koutsomanoli-Filippaki, A., 2008. Cost efficiency of the banking industry in the South Eastern European region. Journal of International Financial Markets, Institutions and Money, 18(5), pp. 483-497. doi: 10.1016/j.intfin.2007.07.003 